\title{
Recurrent wheezing: prevalence and associated factors in infants from Buenos Aires City, Argentina
}

\author{
Gabriela Aída Szulman ${ }^{1,2 *}$, Héctor Freilij ${ }^{1}$, Ise Behrends ${ }^{3}$, Ángela Gentile ${ }^{1}$ and Javier Mallo/4
}

${ }^{1}$ Hospital de Niños Ricardo Gutiérrez; ${ }^{2}$ Universidad de Buenos Aires; ${ }^{3}$ Servicio de Alergia, Hospital Churruca. Autonomous City of Buenos Aires, Argentina; ${ }^{4}$ Departamento de Medicina Respiratoria Infantil, Hospital CRS EI Pino, Escuela de Medicina, Universidad de Santiago de Chile, Santiago de Chile, Chile

\begin{abstract}
Background: The episodes of bronchial obstruction at early age constitute a frequent problem in Pediatrics. This study aimed to evaluate the prevalence of recurrent wheezing in infants in Buenos Aires City and to identify its associated factors. Methods: a Cross-sectional study performed from 2011 to 2012 in the Children Hospital Ricardo Gutiérrez, Buenos Aires City, as part of the International Study of Wheezing in Infants. A validated questionnaire was applied to parents of infants aged between 12 and 15 months. The wheezing prevalence, mainly in recurrent patients (three or more episodes) was evaluated, and its likely associated factors. Data were statistically analyzed employing $\chi^{2}$ test, Fisher's test, binary, and logistics multiple regression analysis, with a significance level of 0.05. Results: Over 1063 infants, 58.9\% (confidence interval (CI) 95\% 55.9-61.9) had at least one episode of wheezing and 26.3\% (C195\% 23.8-29.9) had three or more episodes (recurrent wheezing). Risk factors associated to wheezing were male sex $(p=0.001)$, six or more episodes of cold during the first year of life $(p<0.0001)$, age at first cold $<4$ months $(p<0.0001)$; pneumonia $(p<0.0001)$ and tobacco smoking during pregnan$c y(p=0.01)$. For recurrent wheezing, risk factors we considered as six or more episodes of cold during the first year of life $(p<0.0001)$, early $(<4$ month old) onset wheezing $(p<0.0001)$ and nocturnal wheezing $(p<0.0001)$. Conclusions: The prevalence of recurrent wheezing among infants in Buenos Aires City was high (26.3\%). Some identified associated factors can be preventable.
\end{abstract}

Key words: Recurrent wheezing. Infants. Prevalence. Associated factors. Asthma. Tobacco smoking.

\section{Sibilancias recurrentes: prevalencia y factores asociados en lactantes de Buenos Aires, Argentina}

\section{Resumen}

Introducción: Los episodios de obstrucción bronquial a temprana edad constituyen un problema frecuente en pediatría. El objetivo de este estudio, además de conocer la prevalencia de sibilancias recurrentes en lactantes de Buenos Aires, fue identificar los factores asociados con esta enfermedad. Métodos: Estudio de tipo transversal realizado durante 2011 y 2012, en el Hospital de Niños Ricardo Gutiérrez, Buenos Aires, como parte del Estudio Internacional de Sibilancias en Lactantes,

\section{*Correspondence:}

Gabriela Aída Szulman

Email: szulman.g@gmail.com
Available online: 25-06-2018 Bol Med Hosp Infant Mex. 2017;74:417-424

DOI: 10.24875/BMHIME.M17000014

www.bmhim.com

2444-3409/@ 2018. Hospital Infantil de México Federico Gómez, published by Permanyer México SA de CV, all rights reserved. 
mediante una encuesta validada para padres de lactantes de 12 a 15 meses. Se evaluó la prevalencia de sibilancias, fundamentalmente de tipo recurrentes (tres o más episodios) y los posibles factores asociados. El análisis estadístico se realizó por prueba de $\chi^{2}$, prueba de Fisher y análisis de regresión logística univariada y multivariada. El nivel de significación fue de 0.05. Resultados: De 1063 lactantes, el 58.9\% (intervalo de confianza (IC) 95\% 55.9-61.9) presentaron al menos un episodio de sibilancia y el 26.3\% (IC 95\% 23.8-29.9), tres o más episodios (sibilancias recurrentes). Los factores vinculados a padecer al menos un episodio de sibilancia fueron el sexo masculino $(p=0.001)$, seis o más resfríos en el primer año $(p<0.0001)$, edad del primer resfrío < 4 meses $(p<0.0001)$, neumonía $(p<0.0001)$, tabaquismo durante el embarazo $(p=0.01)$. Los factores relacionados con sibilancias recurrentes fueron seis o más resfríos en el primer año de vida ( $p<0.0001)$, tener el primer episodio de sibilancia antes del cuarto mes de vida $(p<0.0001)$ y sibilancias nocturnas $(p<0.0001)$. Conclusiones: La prevalencia de sibilancias recurrentes en Buenos Aires es alta $(26.3 \%)$. Algunos de los factores asociados serían prevenibles.

Palabras clave: Sibilancias recurrentes. Lactantes. Prevalencia. Factores asociados. Asma. Tabaquismo.

\section{Introduction}

Clinical manifestations due to respiratory diseases in childhood are the most frequent reason for medical consultation, resulting in high demand for health services in all levels of care.1,2

In the International Study of Wheezing in Infants in Latin America (EISL for its Spanish acronym), ${ }^{1}$ the prevalence of infants who had at least one wheezing episode in their first year of life ranged between $22.4 \%$ and $58.9 \%$, with wide variability among the different participating centers.

According to data published in the United States, approximately 800,000 infants ( $20 \%$ of the birth cohort) receive outpatient medical intention in the first 12 months of life for viral respiratory infections. ${ }^{3}$ The primary agent involved is the respiratory syncytial virus (RSV) that affects $90 \%$ of patients younger than 24 months, ${ }^{4}$ of which $40 \%$ develop bronchiolitis. ${ }^{5}$

Obstructive lung disease whose foremost symptom is wheezing remains a frequent problem in pediatrics, especially in the first year of life, since not all patients with recurrent wheezing develop asthma. ${ }^{6}$

Recurrent wheezing occurs in a significant proportion of infants and has been associated with respiratory viral infections, mainly with RSV and rhinovirus, among others.?

On the other hand, the epidemiology of asthma is well known for school-age children, adolescents, and adults. However, the prevalence of recurrent wheezing and associated factors for its development among infants is still under study. Evidence shows an increase in the number of wheezing episodes in infants with a history of viral respiratory infection at an early age. This association has been described even into adulthood in long-term follow-up studies. ${ }^{8-10}$

Therefore, discerning when a wheezing episode is due to a respiratory infection or when it is the beginning of the clinical presentation of asthma at this age is a challenge. ${ }^{11}$

In addition to assessing the prevalence of recurrent wheezing in the first year of life in infants in Buenos Aires, the objective of this study was to identify the factors associated with these episodes.

\section{Methods}

This work, which is part of the EISL, was an observational, analytical, cross-sectional study using a written, standardized and validated survey (k test: 0.98$)^{12}$ aimed at parents of healthy infants aged 12 to 15 months. They went for their checkup and got vaccinated. The questionnaire referred to what happened during the first 12 months of life. This study was conducted from March 2011 to October 2012 at the Consultorio de Niño Sano and the Vaccine Center from the Ricardo Gutiérrez Child Hospital in Buenos Aires (HNRG for its Spanish acronym). 1,063 interviews were conducted. However, for EISL study, we estimated the sample size in each participating center should include at least 984 infants, considering a wheezing prevalence between $25 \%$ and $30 \%$, with a power of $80 \%$ and a significance level of 0.05 .

The questionnaire included 50 questions about what happened in the infants during its first year of life. It included demographic (sex, age, number of siblings, number of cohabitants) and environmental (fuel used for cooking, cohabiting smokers, presence or absence of air conditioning, carpet, pet, cell phone) characteristics. Also, educational (maternal education level) characteristics, breastfeeding and its duration as well as smoking during pregnancy. Family history (mother, father, and siblings) of asthma, rhinitis and allergic dermatitis as well. For infants, respiratory symptoms (age of onset, recurrence of a wheezing episode, colds, pneumonia, presence of a cough, nocturnal wheezing) 
were considered; medication received (inhaled bronchodilators, systemic corticosteroids, inhaled corticosteroids, antileukotrienes, antibiotics, acetaminophen); medical consultations and hospitalizations because of respiratory symptoms.

Before the survey, the medical concept of wheezing and obstructive bronchitis was explained to the interviewee. In the study, the dependent variable "wheeze episodes" was defined as a positive response from parents to the question "Has your baby had one or more episodes of wheezing in the first year of life?" Moreover, categorized as "occasional" (up to two episodes), or "recurrent" (three or more episodes).

Data were recorded in an Excel spreadsheet and analyzed using the statistical package SPSS 16 version (SPSS, Inc., 1989-2007). For all the variables, the distribution of frequencies and percentages was established concerning the total number of cases. For the measurements in ordinal scale or higher the following data were computed: the number of cases, minimum value, maximum value, arithmetic mean, standard deviation, and any other that would have been applicable from the frequency distribution.

The qualitative data were analyzed statistically using the $\chi^{2}$ test or the Fisher test and the univariate and multivariate logistic regression analysis. For the level of significance, a $p \leq 0.05$ was used.

The Ethics Committee and the Teaching and Research Committee of the HNRG of Buenos Aires approved the study, and the written informed consent was obtained for every case.

\section{Results}

At the time of health control or vaccination of their children, 1,147 parents of infants were contacted, of which $92.7 \%$ agreed to be interviewed $(1,063)$. Each one completed the informed consent in writing, of which $96.6 \%$ were mothers, and $3.4 \%$ were parents.

When the survey was conducted, the average age of the infants was 13.28 months (standard deviation (SD) 1.28 months). Of the 1,063 infants, 626 (58.9\%, confidence interval (Cl) $95 \%$ 55.9-61.9\%) had at least one episode of wheezing in the first year of life. Of the 626 patients who had wheezing, $280(44.7 \%, 95 \% \mathrm{Cl}$ $40.8-48.7 \%$ ) had recurrent wheezing (RW). The mean age of the first wheezing episode (occasional and recurrent) was 4.39 months (SD 2.81 months).

According to the demographic, family and clinical characteristics, the comparative analysis of infants with wheezing episodes and those with non-wheezing episodes in the first year of life is shown in table 1. A univariate analysis followed by multivariate analysis adjusted to the following variables were conducted: family asthma, familial rhinitis, the presence of three or more siblings, current maternal smoking, smoking in a partner, hospitalization due to pneumonia, personal atopic dermatitis).

The factors linked to at least one episode of wheezing ( $n=626$ ) were as follows (by multivariate analysis): male sex $(p=0.001)$ (odds ratio $(O R) 1.67,95 \% \mathrm{Cl}$ 1.24-2.24); six or more colds in the first year of life $(p<0.0001$ ) (OR 4.31, 95\% Cl 2.79-6.65); age of the first cold $<4$ months ( $p<0.0001$ ) (OR 2.37, 95\% Cl 1.74-3.23); pneumonia $(p<0.0001)(\mathrm{OR} 16,95 \% \mathrm{Cl}$ 6.92-37.45); smoking during pregnancy $(p=0.01$ ) (OR 1.97, 95\% Cl 1.17-3.31) (Fig. 1).

The comparative analysis of sporadic and recurrent wheezing in the first year of life, according to demographic, family, and clinical characteristics is shown in table 2.

The factors associated with RW (by multivariate analysis) were the following: history of six or more colds in the first year of life $(p<0.0001)(O R 2.92,95 \% \mathrm{Cl}$ 1.83-4.65); presence of the first episode of wheezing before the fourth month of life $(p<0.0001)$ (OR 3.06 , $95 \% \mathrm{Cl} 1.70-5.51)$ and nocturnal wheezing $(\mathrm{p}<0.0001)$ (OR 3.41, 95\% Cl 2.47-4.72) (Fig. 2).

\section{Discussion}

In this study, the prevalence of infants who had wheezing episodes once or more times in their first year of life was $58.9 \%$. These results are similar to those reported in Montevideo (54.5\%), being the highest in the region compared with other centers participating in the EISL study: Bucaramanga (22.4\%), Cuiabá (27.1\%) and Uruguaiana (28.4\%). ${ }^{1}$

The prevalence of infants with RW was $26.3 \%$, similar to that reported by Montevideo (26.4\%) and higher than that reported in Uruguaiana (14\%), Lima (16.6\%) and San Pablo (21.7\%). ${ }^{1}$

The elevated wheezing prevalence in the first year of life, as well as of RW observed in Buenos Aires, and Montevideo could be due to similar climatic factors, given its geographical proximity.

The severity of episodes among patients with RW in our center was the highest in the region. This severity was determined based on the on-call consultations for bronchial obstruction (91.8\%), hospitalization for wheezing $(47.9 \%)$, medical diagnosis of pneumonia $(43.2 \%)$ and hospitalization for pneumonia $(30.7 \%) .^{1}$ It 
Table 1. Comparative analysis between infants with or without wheezing episodes, in the first year of life according to demographic, family, and clinical characteristics

\begin{tabular}{|c|c|c|c|c|}
\hline Variables & $\begin{array}{c}\text { Wheezing (\%) } \\
\mathrm{n}=626(58.9 \%)\end{array}$ & $\begin{array}{l}\text { Not wheezing (\%) } \\
\mathrm{n}=437(41.1 \%)\end{array}$ & $\boldsymbol{p}^{*}$ & $\begin{array}{c}\text { OR } \\
(95 \% \mathrm{CI})^{* *}\end{array}$ \\
\hline Male & 56.9 & 43.9 & $<0.0001$ & $\begin{array}{c}1.67 \\
(1.24-2.24)\end{array}$ \\
\hline Female & 43.1 & 56.1 & & है \\
\hline Birth weight $(\mathrm{kg})$ & 3.20 & 3.24 & 0.214 & (2) \\
\hline Size at birth $(\mathrm{cm})$ & 49.28 & 49.31 & 0.73 & \\
\hline Three or more siblings & 19.5 & 14 & 0.019 & $\underset{c}{\Phi}$ \\
\hline Five or more people in the house & 46.2 & 41.6 & 0.16 & 으 \\
\hline Daycare users & 5.8 & 4.4 & 0.38 & $\frac{0}{0}$ \\
\hline Presence of mold in the house & 40.7 & 37.1 & 0.25 & + \\
\hline Passive smoking & 48.1 & 41.9 & 0.053 & ᄃ \\
\hline Mother currently smoker & 2.3 & 17.8 & 0.05 & $\frac{\omega}{\epsilon}$ \\
\hline Mother who smoked during pregnancy & 13.9 & 6.6 & $<0.0001$ & $\begin{array}{c}1.97 \\
(1.17-3.31)\end{array}$ \\
\hline Kitchen at home & 96.3 & 94.5 & 0.20 & : \\
\hline Complete vaccination scheme & 92.2 & 95 & 0.095 & ¿ \\
\hline History of caesarean section & 34.8 & 35.2 & 0.70 & $\bar{c}$ \\
\hline Average months with exclusive breastfeeding & 5.01 & 5.20 & 0.11 & + \\
\hline Breastfeeding for at least four months & 18.1 & 15.1 & 0.23 & 오 \\
\hline Family history of asthma & 26 & 12.8 & $<0.001$ & 3 \\
\hline Family history of rhinitis & 25.7 & 16.2 & $<0.001$ & $\frac{\varsigma}{>}$ \\
\hline Family history of atopic dermatitis & 13.7 & 9.4 & 0.13 & త \\
\hline Personal history of atopic dermatitis & 27.8 & 20.4 & 0.007 & $\stackrel{0}{c}$ \\
\hline Six or more colds & 38.9 & 7.1 & $<0.0001$ & $\begin{array}{c}4.31 \\
(2.79-6.65)\end{array}$ \\
\hline First cold before 4 months old & 57.9 & 27.1 & $<0.0001$ & $\begin{array}{c}2.37 \\
(1.74-3.23)\end{array}$ \\
\hline Pneumonia & 29.6 & 1.4 & $<0.0001$ & $\begin{array}{c}16 \\
(6.92-37.45\end{array}$ \\
\hline Hospitalization due to pneumonia & 20.1 & 1.1 & $<0.0001$ & बे \\
\hline
\end{tabular}

OR, odds ratio; $95 \% \mathrm{Cl}, 95 \%$ confidence interval.

* Significant $P$ of the univariate analysis

was also noted that the presence of six or more viral respiratory infections in the first year and less than four months after the initial viral respiratory infection age constituted associated factors to the presence of at least one episode of wheeze and RW, harmonizing with previous studies. ${ }^{13-20}$
Several investigations showed a clear association between viral respiratory infections at an early age and the development of wheezing. ${ }^{21-25}$ Other studies concluded that respiratory viral infections in infants, both mild (common cold) and severe (bronchiolitis), would be a predisposing factor for the 
Table 2. Comparative analysis between occasional wheezing and recurrent wheezing in the first year of life according to demographic, family, and clinical characteristics

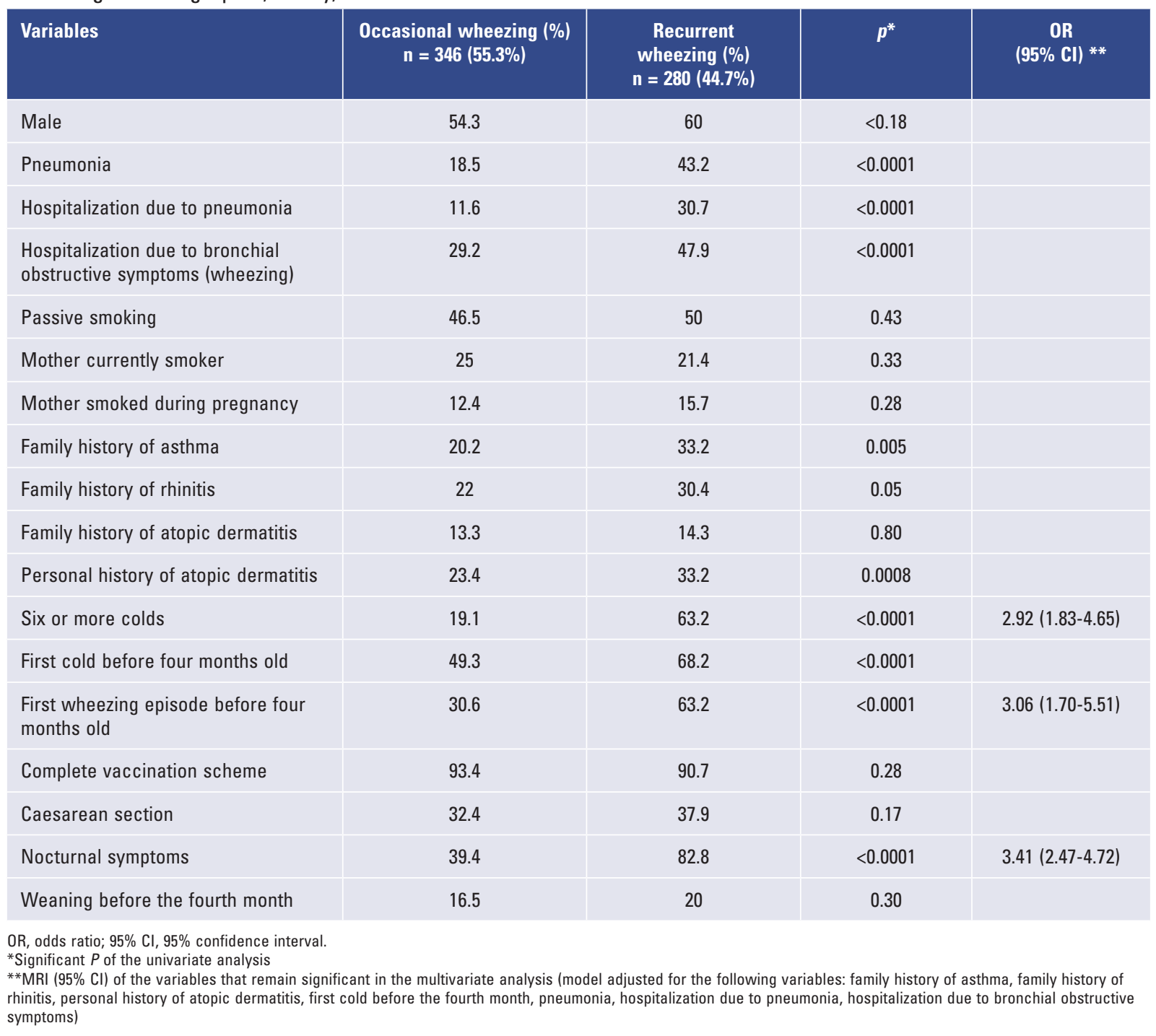

development of allergic sensitization later in childhood and adolescence..$^{13}$

In Finland, patients hospitalized for rhinovirus with bronchiolitis had an increased risk of asthma. This relationship was maintained until they were ten years old. 14,15

In Spain, in a recently published study, viral respiratory infections were evaluated in a cohort of newborns using PCR (polymerase chain reaction). It was detected that the rhinovirus was the agent most frequently involved. The authors showed that infants who required hospitalization for their first viral infection had an increased risk of developing recurrent wheezing, compared to infants whose first viral infection was mild or asymptomatic. $^{26}$
Furthermore, Bønnelykke et al. ${ }^{16}$ evaluated the association between viral respiratory infections (HRSV, rhinovirus, among others) and bacterial infections in infants, and the development of asthma in childhood. They concluded that the total number of respiratory infections suffered at an early age was a risk factor for developing asthma, regardless of the specific causal agent.

One of the factors associated with the development of at least one episode of wheezing was the male gender, coinciding with previous publications. ${ }^{27-29}$ It has been reported that male infants usually have lower VmaxFRC values (maximum expiratory flow at the functional residual capacity level) in comparison to female infants, ${ }^{30}$ which could explain the development of wheezing in male patients in this age group. 


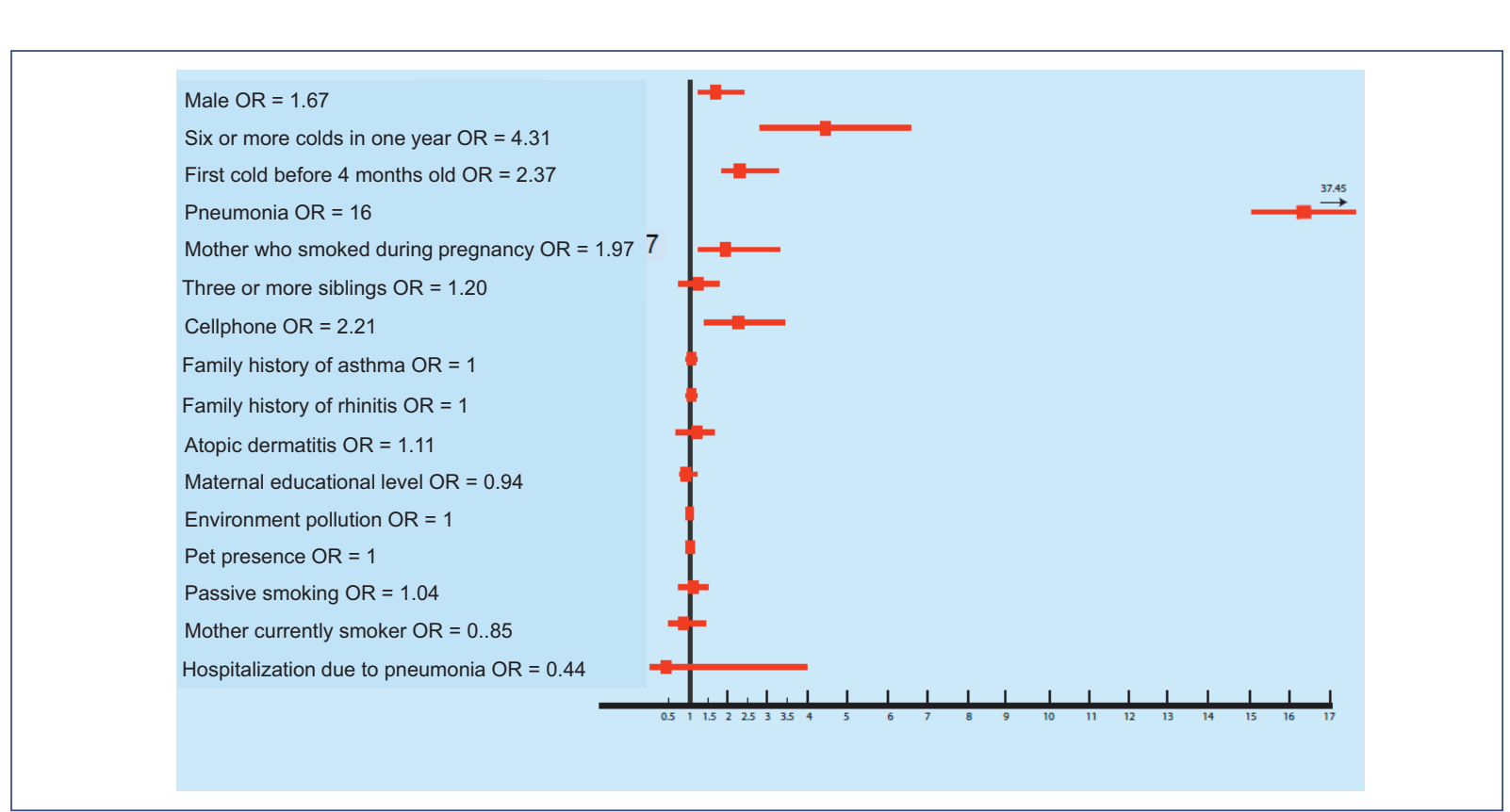

Figure 1. Risk factors associated with 626 infants with wheezing in the first year of life (multivariate analysis). OR, odds ratio.

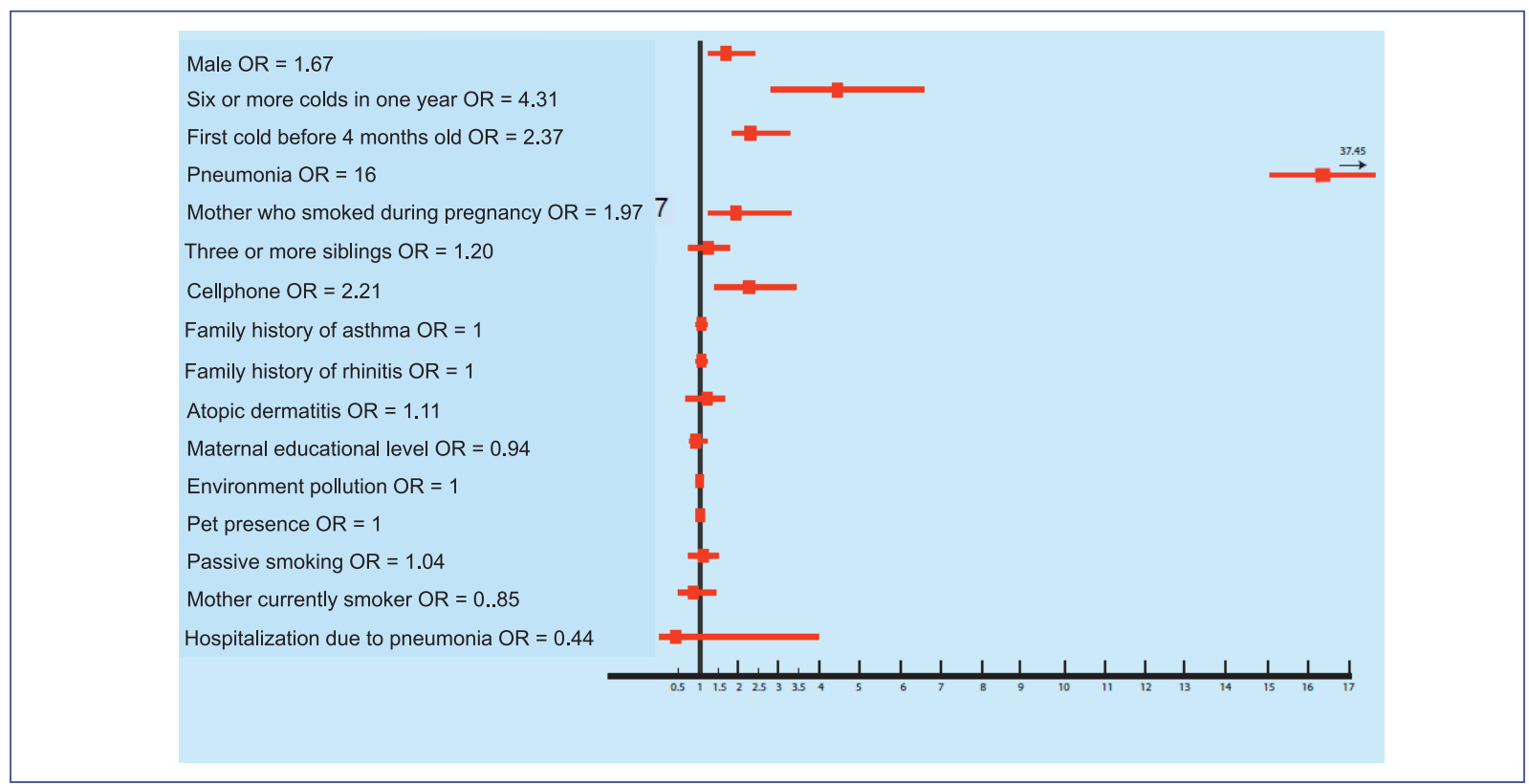

Figure 2. Risk factors associated with 280 infants with recurrent wheezing (three or more episodes) in the first year of life (multivariate analysis). OR, odds ratio.

Patients who underwent at least one episode of wheezing were 16 times more likely to suffer from pneumonia than those without any episode of wheezing. In long-term follow-up studies, it was shown that in children $<2$ years of age who had suffered bronchiolitis or pneumonia, the prevalence of wheezing increased even in adulthood. ${ }^{31-33}$
The prevalence of mothers who smoked during pregnancy was $10.9 \%(95 \% \mathrm{Cl} 9.13-12.9 \%)$. In the United States, the prevalence ranges from $10 \%$ to $20 \%$. ${ }^{34,35}$ This study also showed that smoking during pregnancy is an associated factor with at least one episode of wheezing during the first year of life. Similar findings were reported in Latin America and Europe.1,2,28 In 
mothers who smoke during pregnancy, and even in those who are exposed to secondhand smoke, there is an alteration in the fetal immune response, with a decrease in helper T lymphocytes (CD4 +) and an increase in allergic risk, favoring obstructive bronchial episodes. ${ }^{36-39}$ These alterations could explain, in part, the results observed. Prenatal exposure to maternal smoking decreases pulmonary compliance even further, reducing elastin in the pulmonary interstitium reducing small airways caliber.

Exposure to tobacco smoke was of $45.5 \%$. However, it was not an associated factor for the development of wheezing. Other authors found that exposure to second-hand smoke increases bronchial hyper reactivity proportionally to the number of cigarettes smoked at home; It has even been shown to increase the incidence of asthma in children and adolescents by at least $20 \%{ }^{38}$

Breastfeeding among studied infants was not a protective factor against episodes of wheezing. However, it was a clear protection factor in the EISL throughout Latin America. ${ }^{1}$ These differences could be due to the number of patients surveyed.

In this study, infants with RW were 3.4 times more likely to present nocturnal wheezing compared to patients with occasional wheezing. Reports in the latest standard of the Global Initiative for Asthma (GINA), ${ }^{11}$ showed that infants with recurrent episodes of wheezing, including sleep, guide the diagnosis of asthma. Also, in a study where children from 6 to 20 months old who suffered from RW and had risk factors for developing asthma (family history of asthma or another finding of atopy in one or both parents) were evaluated, a decrease in lung function Vmax FRC was confirmed. ${ }^{40}$

It seems that the key to the development of wheezing is in the immunogenic and environmental interaction, in both the fetal period and the first months of life.

The elevated prevalence of recurrent wheezing and its severity expressed in data from hospitalizations and emergency visits for obstructive bronchial symptoms are a fundamental reason for the economic and work burden of health centers and parents.

One limitation was that in a cross-sectional study it is difficult to recognize without a doubt the predictor of the outcome, which would not occur in a longitudinal cohort study. For this reason, some of the factors identified associated with the presence of both occasional and recurrent wheezing could be prevented if their causality was confirmed in a longitudinal cohort study.

The implementation of public health actions aimed at reducing early viral respiratory infections and avoiding maternal smoking in pregnancy could result in a decrease in the prevalence and severity of wheezing episodes in the first year of life.

\section{Ethical disclosures}

Protection of human and animal subjects. The authors declare that no experiments were performed on humans or animals for this study.

Confidentiality of data. The authors declare that they have followed the protocols of their work center on the publication of patient data.

Right to privacy and informed consent. The authors declare that no patient data appear in this article.

\section{Conflict of interest}

The authors declare that they have no conflicts of interest.

\section{Funding}

None.

\section{Acknowledgments}

To Dario Rajmilovich, Jana Cao, and Dr. Vicente Castiglia.

\section{References}

1. Mallol J, Solé D, Garcia-Marcos L, Rosario N, Aguirre V, Chong H, et al. Prevalence, severity, and treatment of recurrent wheezing during the first year of life: A cross-sectional study of 12,405 Latin American infants. Allergy Asthma Immunol Res. 2016;8:22-31.

2. Mallol J, García-Marcos L, Solé D, Brand P, EISL Study Group.International prevalence of recurrent wheezing during the first year of life: variability, treatment patterns and use of health resources. Thorax. 2010:65:1004-9.

3. Hall CB, Weinberg GA, Iwane MK, Blumkin AK, Edwards KM, Staat MA et al. The burden of RSV infection in young children. $\mathrm{N}$ Engl $\mathrm{J}$ Med. 2009;360:588-98.

4. Greenough A, Cox S, Alexander J, Lenney W, Turnbull F, Burgess S, et al. Health care utilisation of infants with chronic lung disease, related to hospitalisation for RSV infection. Arch Dis Child. 2001;85:463-8.

5. Meissner HC. Selected populations at increased risk from respiratory syncytial virus infection. Pediatr Infect Dis J. 2003;22:s40-4.

6. Martinez F, Wright A, Taussig L, Holberg C, Halonen M, Morgan W. Asthma and wheezing in the first six years of life. The Group Health Medical Associates. New Engl J Med.1995;332:133-8.

7. Kleninger E, Fuchs $O$, Latzin P, Frey U, Regamey N. Rhinovirus infections in infancy and early childhood. Eur Resp J. 2013;41:443-52.

8. Sigurs N, Aljassim F, Kjellman B, Robinson PD, Sigurbergsson F, Bjarnason $\mathrm{R}$, et al. Asthma and allergy patterns over 18 years after severe RSV bronchiolitis in the first year of life. Thorax. 2010;65:1045-52.

9. Chan JYC, Stern DA, Guerra S, Wright AL, Morgan WJ, Martínez FD. Pneumonia in childhood and impaired lung function in adults: a longitudinal study. Pediatrics. 2015;135:607-16.

10. Caliskan M, Bochkow YA, Kreiner-Moller E, Bønnelykke K, Stein MM, Du G, et al. Rhinovirus wheezing illness and genetic risk of childhood-onset asthma. N Engl J Med. 2013;368:1398-407.

11. Global Initiative for Asthma. Global Strategy for Asthma Management and Prevention, 2017. www.ginasthma.org. 
12. Mallol J, Garcia-Marcos L, Aguirre V, Martinez-Torres A, Perez-Fernandez V, Gallardo A, et. al. The International Study of Wheezing in Infants: questionnaire validation. Int Arch Allergy Immunol. 2007;144:44-50.

13. Jackson D, Evans M, Gangnon R, Tisler C, Pappas T, Lee W, et al. Evidence for a causal relationship between allergic sensitization and rhinovirus wheezing in early life. Am J Respir Crit Care Med. 2012;185: 281- 5.

14. Hyvarinen M, Kotaniemi-Syrjanen A, Reijonen T, Korhonen K, Korppi M. Teenage asthma after severe early childhood wheezing: an 11-yea prospective follow-up. Pediatr Pulmonol. 2005;40:316-23

15. Kotaniemi-Syrjanen A, Vainionpaa R, Reijonen T, Waris M, Korhonen K, Korppi M. Rhinovirus-induced wheezing in infancy-the first sign of childhood asthma? J Allergy Clin Immunol. 2003;111:66-71.

16. Bønnelykke K, Vissing N, Sevelsted A, Johnston S, Bisgaard H. Association between respiratory infections in early life and later asthma is independent of virus type. J Allergy Clin Immunol. 2015;136:81-6.

17. Sly $\mathrm{P}$, Boner A, Björksten A, Bush A, Custovic A, Eigenmann $\mathrm{P}$, et al Early identification of atopy in the prediction of persistent asthma in children. Lancet 2008;372:1100-6.

18. Stein R, Sherrill D, Morgan W, Holberg C, Halonen M, Taussig L, et al. Respiratory syncytial virus in early life and risk of wheeze and allergy by age 13 years. Lancet. 1999;354:541-5.

19. Régnier S, Huels J. Association between respiratory syncytial virus hospitalizations in infants and respiratory sequelae: systematic review and meta-analysis. Pediatr Infect Dis J. 2013;32:820-6.

20. Szabo S, Levy A, Gooch K, Bradt P, Wijaya H, Mitchell I. Elevated risk of asthma after hospitalization for respiratory syncytial virus infection in infancy. Paediatr Respir Rev. 2013:13:S9-15.

21. Busse W, Lemanske R Jr, Gern J. Role of viral respiratory infections in asthma and asthma exacerbations. Lancet. 2010;376:826-34.

22. Mommers M, Thijs C, Stelma F, Penders F, Reimerink J, van Ree E, et al. Timing of infection and development of wheeze, eczema, and atopic sensitization during the first 2 years of life: the KOALA Birth Cohort Study. Pediatr Allergy Immunol. 2010;21:983-9.

23. Sigurs N, Gustafsson PM, Bjarnason R, Lundberg F, Schmidt S, Sigurbergsson $\mathrm{F}$, et al. Severe respiratory syncytial virus bronchiolitis in infancy and asthma and allergy at age 13. Am J Respir Crit Care Med. 2005; 171:137-41.

24. Kuehni C, Spycher B, Silverman M. Causal links between RSV infection and asthma: no clear answers to an old question. Am J Respir Crit Care Med. 2009;179:1079-80.

25. Jackson D, Gangnon R, Evans M, Roberg K, Anderson E, Pappas T, et al. Wheezing rhinovirus illnesses in early life predict asthma development in high-risk children. Am J Respir Crit Care Med. 2008;178: 667-72.

26. Calvo C, Aguado I, García-García M, Ruiz-Chercoles E, Díaz-Martínez E, Albañil $R$, et.al. Infecciones virales respiratorias en una cohorte de niños durante el primer año de vida y su papel en el desarrollo de sibilancias. An Pediatr (Barc). 2016;2143:1-7.

27. Medeiros D, Silva A, Rizzo J, Sarinho E, Mallol J, Solé D, et al. [Prevalência de sibilância e fatores de risco associados em crianças no primeiro ano de vida, residentes no Município de Recife, Pernambuco, Brasil]. Cad Saúde Pública. 2011;27:1551-9.

28. Garcia-Marcos L, Mallol J, Solé D, Brand P, EISL Study Group. International study of wheezing in infants: risk factors in affluent and non-affluent countries during the first year of life. Pediatr Allergy Immunol. 2010:21:878-88.

29. Pérez Tarazona S, Alfonso Diego J, Amat Madramany A, Chofre Escrihuela L, Lucas Sáez E, Bou Monterde R. Incidencia y factores de riesgo de bronquitis sibilantes en los primeros 6 meses de vida en una cohorte de Alzira (Valencia). An Pediatr (Barc). 2010;72:19-29.

30. Tepper R, Morgan W, Cota K, Wright A, Taussig LM, Ghma Pediatricians. Physiologic growth and development of the lung during the first year of life. Am Rev Respir Dis. 1986;134:513-9.

31. Hyvärinen M, Piippo-Savolainen E, Korhonen K, Korppi M-Teenage asthma after severe infantile bronchiolitis or pneumonia. Acta Paediatr. 2005;94:1378-83.

32. Piippo-Savolainen E, Remes S, Kannisto S, Korhonen K, Korppi M. Asthma and lung function 20 years after wheezing in infancy: results from a prospective follow-up study. Arch Pediatr Adolesc Med. 2004;158:1070-6.

33. Backman K, Piippo-Savolainen E, Ollikainen H, Koskela H, Korppi M. Increased asthma risk and impaired quality of life after bronchiolitis or pneumonia in infancy. Pediatr Pulmonol. 2014;49:318-25.

34. Ananth C, Kirby R, Kinzler W. Divergent trends in maternal smoking during pregnancy: United States 1990-99. Pediatr Perinat Epidemiol. 2005;19:19-26.

35. Colman G, Joyce T. Trends in smoking before, during, and after pregnancy in ten states. Am J Prev Med. 2003;24:29-35.

36. De la Chica RA, Ribas I, Giraldo J, Egozcue J, Fuster C. Chromosomal instability in amniocytes from fetuses of mothers who smoke. JAMA. 2005;293:1212-22.

37. Noakes $P$, Hale J, Thomas R, Lane C, Devadason S, Prescott S, Maternal smoking is associated with impaired neonatal toll-like-receptor-mediated immune responses. Eur Respir J. 2006;28:721-9.

38. Burke H, Leonardi-Bee J, Hashim A, Pine-Abata H, Chen Y, Cook DG et al. Prenatal and passive smoke exposure and incidence of asthma and wheeze: systematic review and meta-analysis. Pediatrics. 2012;129:735-44.

39. Schvartsman C, Farhat S, Schvartsman S, Saldiva P. Parental smoking patterns and their association with wheezing in children. Clinics (Sao Paulo). 2013;68:934-9.

40. Teper A, Kofman C, Szulman G, Vidaurreta S, Maffey A. Fluticasone improves pulmonary function in children under 2 years old with risk factors for asthma. Am J Respir Crit Care Med. 2005;171:587-90. 